\title{
Effect of Moderate Drought Stress on Photosynthetic Rate and Grain Yield in Finger Millet Genotypes
}

\author{
Y.A. Nanja Reddy ${ }^{1,2 *}$, Jayarame Gowda ${ }^{2}$, E.G. Ashok ${ }^{2}$ and K.T. Krishne Gowda ${ }^{2}$ \\ ${ }^{1}$ Department of Crop Physiology, ${ }^{2}$ AICRP on Small Millets, University of Agricultural \\ Sciences, GKVK, Bangalore 560065, Karnataka, India
}

\section{A B S T R A C T}

\begin{tabular}{l} 
K e y w o r d s \\
$\begin{array}{l}\text { Finger millet, } \\
\text { Photosynthetic rate, } \\
\text { Mean ear weight, } \\
\text { Grain yield }\end{array}$ \\
\hline Article Info \\
$\begin{array}{l}\text { Accepted: } \\
23 \text { April } 2020 \\
\text { Available Online: } \\
\text { 10 May } 2020\end{array}$ \\
\hline
\end{tabular}

In the changing climate scenario, drought could be continued as a major abiotic limitation for crop productivity. Finger millet although known for its drought tolerance, the drought stress decreases the grain yield from 25 to 100 percent depending on the duration and magnitude of drought stress. Present study was conducted to explore the genetic variability of selected genotypes over the ruling varieties if any, based on the extent of reduction in grain yield, and dependent photosynthetic traits due to moderate drought stress for 18 to 20 days (grand growth to flower primordial initiation). Five selected genotypes were compared with three released varieties under field condition by withholding the irrigation for stress treatment. Moderate drought stress for a period of 18 to 20 days decreased the photosynthetic rates markedly due to decreased stomatal conductance and transpiration rates. However, yield reduction was less than 6.0 per cent in released varieties. Correlations and path analysis proved that, the mean ear weight and productive tillers per hill are important in yield determination of finger millet under drought condition. Among the varieties, Cv. PR-202 found relatively drought tolerant and this variety can be used as check for screening germplasm accessions against the drought stress. It is concluded that, moderate drought stress for 18 to 20 days with pan evaporation of around $4 \mathrm{~mm}$ per day is not a serious limitation under rainfed situations during kharif seasons.

\section{Introduction}

Finger millet belongs to family Poaceae (Dida et al., 2007) with $\mathrm{C}_{4}$ pathway (Ueno et al., 2006; Sage and Zhu, 2011) suitable to rainfed situations. Finger millet is grown in arid and semi-arid regions in more than 25 countries, predominantly in India and Africa. The grain is nutritionally rich in calcium, iron, zinc, magnesium, potassium, and others with low glycemic index and presence of anti- nutritional factors like phytic acid and tannins (Chethan and Malleshi, 2007; Devi et al., 2014; Gupta et al., 2017; Sharma et al., 2017; Netravathi et al., 2018; Nanja Reddy et al., $2019 b$ ). Owing to its nutritional quality and to meet the regional food and fodder security, it is cultivated as rainfed crop in $90 \%$ of finger millet area (Davis et al., 2019). In India, it is cultivated in an area of $1.19 \mathrm{~m}$ ha with production of $2.0 \mathrm{~m} \mathrm{t}$ with a major contribution $(58 \%)$ from the state of 
Karnataka (Malhotra, 2018, Sakamma et al., 2018). Under rainfed conditions drought stress (DS) for 15 to 30 days is a common feature and will continue as a major abiotic limitation for productivity in the changing climate scenario.

Drought stress (DS) affect the crop yield for instance, a $10 \%$ drop in rainfall results in 4.2 $\%$ decrease in grain yield of cereal crops (Webb and Braun, 1994). Simulation models predict that DS reduces the grain yield of wheat and maize to the extent of 21 to $40 \%$ on global scale (Daryanto et al., 2014). Drought stress for 25 to 30 days invariably occurs during one or the other crop growth stages during monsoon season and decreases the grain yield finger millet up to $25 \%$ (Anon, 2008). While prolonged DS from 28 DAS to till the crop maturity decreased the grain yield by $109.8 \%$ (Maqsood and Azam Ali, 2007).

Recently, it is predicted that Indian monsoon precipitation would increase in future years due to increasing vaporization accountable to increase in $\mathrm{CO}_{2}$, aerosols and deforestation (Jalihal et al., 2019). However, the frequency of DS is increasing with irregular distribution of rainfall and a fewer rainy days during monsoon season (Dash et al., 2009). The rainfall pattern from 2010 to 2019 at the experimental station show that, during cropping season (July to October), the rainfall was $526.4 \pm 153.3 \mathrm{~mm}$ with $32.5 \pm 13.9$ rainy days, suggesting a highly unpredictable variations in rainfall distribution during monsoon season (Anon, 2019). For these situations, relatively finger millet is the most suitable crop as it is highly climate resilient compared to other major cereal crops. However, owing to reduction in grain yield due to DS, studies on elite genotypes in comparison with popular varieties could be useful to explore the genetic variability. In any genotype, the grain yield under DS is the product of biomass and harvest index, but the yield attributing characters are determined by the photosynthetic capacity of a genotype. Therefore, a study was conducted to quantify the effect of moderate drought stress (grand growth stage to flower primordial initiation) on gas exchange traits and yield attributing characters in selected finger millet genotypes.

\section{Materials and Methods}

Experiment was conducted at the field Unit, AICRP (Small Millets), Zonal Agricultural Research Station, University of Agricultural Sciences, GKVK, Bengaluru-65 during kharif, 2008. The location is situated at $12^{\circ} 58^{1}$ North latitude and $77^{\circ} 35^{1}$ East longitude at an altitude of 930 meter above the MSL and has red sandy loam soil. Eight selected genotypes (given with results) were sown directly in the field on $28^{\text {th }}$ July 2008 and thinned to single plant per hill within 20 days after sowing (DAS). The experiment was planned in split plot design with eight genotypes in three replications. Each replication had 13 rows of $3.0 \mathrm{~m}$ length in the spacing of $30 \mathrm{~cm}$ between rows and $10 \mathrm{~cm}$ between plants. The gross plot size was $3.9 \mathrm{~m}$ x $3.0 \mathrm{~m}\left(11.7 \mathrm{~m}^{2}\right)$. During the crop growth period, rainfall did not occur from $10^{\text {th }}$ Sept to $4^{\text {th }}$ October, 2008 (25 days), during this 25 day period, two irrigations of $10 \mathrm{~mm}$ each were provided to rainfed treatment called as control and; the other treatment drought stress (DS) was continued to be under stress condition for 25 days. These two plots were separated by $3.0 \mathrm{~m}$ apart to avoid the irrigation drift. The crop growth phase during stress period was coincided from grand growth to initiation of ear emergence. The fertilizer dose was 50:40:25 kg ha-1 $(\mathrm{N}$ : $\mathrm{P}$ : K respectively) was applied. The entire dose of $\mathrm{P}$ and $\mathrm{K}$; and half dose of nitrogen were applied at the time of sowing. The remaining $\mathrm{N}$ was supplied 40 days after sowing. Two hand weedings were taken before 30 DAS. 
The details of rainfall and the stress treatment are as follows; on $9^{\text {th }}$ September 2008, 26.4 $\mathrm{mm}$ rainfall was occurred. It could take nearly 6 days for exhausting (to initiate drought stress) the preceding rainfall of $26.4 \mathrm{~mm}$ with existed average pan evaporation was $4.2 \mathrm{~mm}$ per day. The total pan evaporation during the stress period was $113.9 \mathrm{~mm}$, with rainfall of 26.4; hence the net deficit of rainfall was $107.5 \mathrm{~mm}$ in 18 days@ $4.2 \mathrm{~mm} \mathrm{~d}^{-1}$. This stress period for 18 to 20 days is called moderate drought stress.

At the end of stress period, gas exchange parameters were measured using Infrared Gas Analyzer (IRGA) (LI 6400) from 10.00 to $11.00 \mathrm{AM}$ on fully expanded $3^{\text {rd }}$ leaf from the apex. The measurements were made from $21^{\text {st }}$ (15 days of actual stress) to $23^{\text {nd }}$ day (17 days of actual stress) after stress imposition. The yield attributes viz., productive tillers, mean ear weight, finger length and number of fingers per ear was measured at the time of harvest. The grain yield was recorded in net plot area of 11 rows leaving the border rows and two hills on each side of the row $(2.6 \mathrm{~m} \mathrm{x}$ $2.7 \mathrm{~m}$ ). The productive tiller number and other parameters were recorded in 1.0 meter row length of 10 plants. The data was statistically analyzed in split plot design for genotypic performance. Pearson correlations between traits and the path analysis was followed to identify the contribution of each trait towards grain yield using OPSTAT package developed CCSHAU, Hisar (Sheoran et al., 1998).

\section{Results and Discussion}

$\mathrm{C}_{4}$ photosynthesis is most efficient due to $\mathrm{CO}_{2}$ concentrating mechanism in bundle sheath cells and high RuBisCo activity with a reduction in photorespiration (Sage and Zhu, 2011). However, the moderate drought stress (DS) for 18 days during grand growth stage to panicle primordial initiation, significantly decreased the mean photosynthetic rate by 16.6 per cent (Table 1; Mohanabharathi et al., 2019). Significant genotypic variations for photosynthetic rate were observed both under control and stress condition. Under stress condition, Cv. PR-202 recorded highest photosynthetic rate $\left(31.5 \mathrm{u} \mathrm{Mol} . \mathrm{m}^{-2} \mathrm{~s}^{-1}\right)$ with a least per cent reduction of only 4.0 per cent. Similar genotypic variations in photosynthetic rates under stress conditions were reported (Subramanyam, 2000; Gupta et al., 2011).

Higher photosynthetic rate in PR-202 under moderate drought stress was due to higher stomatal conductance and transpiration rates. This suggests that per unit of water transpired the $\mathrm{CO}_{2}$ uptake was high, thus resulted in higher carboxylation and photosynthetic rate. Higher stomatal conductance in Cv. PR-202 infers that, it has better water relations as character per se. The photosynthetic rate was positively and markedly related to stomatal conductance and transpiration rate under control condition (Table 2: Anitha et al., 2019; Mohanabharathi et al., 2019; Maai et al., 2020). However, the relationship was highly significant under stress condition $(\mathrm{r}=$ $0.804^{*}$ and $0.811^{* *}$ respectively). This suggests that, stomatal responses are important under drought stress condition.

Moderate DS decreased the mean grain yield by $9.5 \%$ (Table 3; Suma, 2014; Mohanabharathi et al., 2019). The grain yield due to stress was less affected in Cv. PR-202 (5.6\%), MR-6 (5.3\%) and HR-911 (6.4 \%). But the absolute grain yield under stress was higher in MR-6 (35.8), GE-1034 (35.8), GE1013 (36.0 q ha ${ }^{-1}$ ), and HR-911 (37.2) as compared to PR-202. However, only HR-911 was significantly superior over the $\mathrm{Cv}$. PR202. The productive tillers per hill influence the grain yield of finger millet positively (Nanja Reddy et al., 2019a). 
Table.1 Influence of moderate drought stress on photosynthetic characters in selected finger millet genotypes

\begin{tabular}{|c|c|c|c|c|c|c|c|c|c|c|c|c|}
\hline \multirow[t]{2}{*}{ Variety } & \multicolumn{4}{|c|}{$\begin{array}{l}\text { Photosynthetic rate } \\
\qquad\left(\mathrm{u} \mathrm{mol} \mathrm{m} \mathrm{mol}^{-2} \mathrm{~s}^{-1}\right)\end{array}$} & \multicolumn{4}{|c|}{$\begin{array}{l}\text { Conductance } \\
\left(\mathrm{mol} \mathrm{m}^{-2} \mathrm{~s}^{-1}\right)\end{array}$} & \multicolumn{4}{|c|}{ 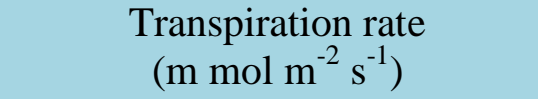 } \\
\hline & $\mathrm{C}$ & DS & Mean & $\%$ Red. & $\mathrm{C}$ & DS & Mean & $\%$ Red. & $\mathrm{C}$ & DS & Mean & $\%$ Red. \\
\hline GE - 1013 & 27.8 & 25.9 & 26.9 & 6.8 & 0.22 & 0.19 & 0.21 & 13.6 & 4.06 & 2.88 & 3.47 & 29.1 \\
\hline GE - 3069 & 35.6 & 26.6 & 31.1 & 25.3 & 0.22 & 0.20 & 0.21 & 9.1 & 4.43 & 3.34 & 3.89 & 24.6 \\
\hline PR - 202 & 32.1 & 30.8 & 31.5 & 4.0 & 0.30 & 0.31 & 0.31 & -3.3 & 4.55 & 3.43 & 3.99 & 24.6 \\
\hline GE - 3457 & 26.7 & 23.2 & 25.0 & 13.1 & 0.16 & 0.15 & 0.16 & 6.3 & 3.31 & 2.71 & 3.01 & 18.1 \\
\hline GE - 4777 & 29.4 & 24.5 & 27.0 & 16.7 & 0.19 & 0.15 & 0.17 & 21.1 & 3.30 & 2.73 & 3.02 & 17.3 \\
\hline HR - 911 & 32.7 & 28.2 & 30.5 & 13.8 & 0.27 & 0.15 & 0.21 & 44.4 & 3.70 & 3.06 & 3.38 & 17.3 \\
\hline MR - 6 & 31.2 & 22.2 & 26.7 & 28.8 & 0.23 & 0.14 & 0.19 & 39.1 & 3.50 & 2.47 & 2.99 & 29.4 \\
\hline GE - 1034 & 32.4 & 24.6 & 28.5 & 24.1 & 0.23 & 0.16 & 0.20 & 30.4 & 3.74 & 2.26 & 3.00 & 39.6 \\
\hline \multirow[t]{2}{*}{ Mean } & 31.0 & 25.8 & 28.4 & 16.6 & 0.23 & 0.18 & 0.21 & 20.1 & 3.83 & 2.86 & 3.35 & 25.0 \\
\hline & SEm & $\mathrm{CD}$ & & & SEm & $\mathrm{CD}$ & & & SEm & $\mathrm{CD}$ & & \\
\hline Treatment & 0.21 & 0.61 & & & 0.003 & 0.01 & & & 0.05 & 0.14 & & \\
\hline Variety & 0.42 & 1.21 & & & 0.005 & 0.01 & & & 0.09 & 0.26 & & \\
\hline $\mathrm{V} \times \mathrm{T}$ & 0.60 & 1.73 & & & 0.007 & 0.02 & & & 0.13 & 0.38 & & \\
\hline $\mathrm{CV}(\%)$ & \multicolumn{2}{|c|}{4.7} & & & \multicolumn{2}{|c|}{6.2} & & & \multicolumn{2}{|c|}{6.8} & & \\
\hline
\end{tabular}


Table.2 Pearson Correlation between photosynthetic parameters in finger millet genotypes under control and moderate drought stress conditions

\begin{tabular}{|l|c|c|c|c|c|c|}
\hline Character & \multicolumn{3}{|c|}{ Control } & \multicolumn{3}{c|}{ Drought Stress } \\
\hline & $\mathrm{A}$ & $\mathrm{g}_{\mathrm{s}}$ & $\mathrm{T}$ & $\mathrm{A}$ & $\mathrm{g}_{\mathrm{s}}$ & $\mathrm{T}$ \\
\hline Photosynthetic rate (A) & 1.000 & & & 1.000 & & \\
\hline Stomatal conductance $\left(\mathbf{g}_{\mathrm{s}}\right)$ & 0.565 & 1.000 & & 0.804 & 1.000 & \\
\hline Transpiration rate $(\mathbf{T})$ & 0.564 & 0.647 & 1.000 & 0.811 & 0.716 & 1.000 \\
\hline
\end{tabular}

Table.3 Influence of moderate stress on seed yield and yield related parameters in selected finger millet genotypes

\begin{tabular}{|c|c|c|c|c|c|c|c|c|c|c|c|c|c|c|c|c|c|c|c|c|}
\hline \multirow[t]{2}{*}{ Variety } & \multicolumn{4}{|c|}{ Seed yield $\left(\mathrm{q} \cdot \mathrm{ha}^{-1}\right)$} & \multicolumn{4}{|c|}{ Mean ear wt. (g) } & \multicolumn{4}{|c|}{ Prod. tillers/ mrl } & \multicolumn{4}{|c|}{ Ear length (cm) } & \multicolumn{4}{|c|}{ Fingers/ Earhead } \\
\hline & $\mathrm{C}$ & DS & Mean & $\%$ Red. & $\mathrm{C}$ & DS & Mean & $\% \mathrm{Rd}$. & $\mathrm{C}$ & DS & Mean & $\% \mathrm{Rd}$ & $\mathrm{C}$ & DS & Mean & $\% \mathrm{Rd}$ & $\mathrm{C}$ & DS & Mean & $\% \mathrm{Rd}$. \\
\hline GE - 1013 & 40.0 & 36.0 & 38.0 & 10.0 & 6.33 & 6.25 & 6.29 & 1.3 & 29.3 & 31.3 & 30.3 & -6.8 & 7.62 & 7.65 & 7.64 & -0.4 & 7.53 & 8.07 & 7.80 & -7.2 \\
\hline GE - 3069 & 20.0 & 17.4 & 18.7 & 13.0 & 5.46 & 4.91 & 5.19 & 10.1 & 37.3 & 27.3 & 32.3 & 26.8 & 8.00 & 7.47 & 7.74 & 6.6 & 8.01 & 6.13 & 7.07 & 23.5 \\
\hline PR - 202 & 36.0 & 34.0 & 35.0 & 5.6 & 4.51 & 4.37 & 4.44 & 3.1 & 48.3 & 46.7 & 47.5 & 3.3 & 5.13 & 4.87 & 5.00 & 5.1 & 6.43 & 6.90 & 6.67 & -7.3 \\
\hline GE - 3457 & 32.1 & 27.7 & 29.9 & 13.7 & 4.66 & 4.44 & 4.55 & 4.7 & 32.0 & 31.0 & 31.5 & 3.1 & 5.47 & 5.09 & 5.28 & 7.0 & 7.10 & 6.63 & 6.87 & 6.6 \\
\hline GE - 4777 & 31.5 & 25.9 & 28.7 & 17.8 & 6.26 & 5.57 & 5.92 & 11.0 & 27.0 & 24.3 & 25.7 & 10.0 & 5.79 & 5.28 & 5.54 & 8.8 & 8.27 & 7.60 & 7.94 & 8.1 \\
\hline HR - 911 & 39.6 & 37.2 & 38.4 & 6.4 & 6.49 & 7.20 & 6.85 & -10.9 & 31.7 & 31.7 & 31.7 & 0.0 & 8.05 & 7.90 & 7.98 & 1.9 & 7.83 & 7.57 & 7.70 & 3.3 \\
\hline MR - 6 & 37.8 & 35.8 & 36.8 & 5.3 & 5.28 & 5.54 & 5.41 & -4.9 & 32.3 & 31.7 & 32.0 & 1.9 & 8.42 & 7.55 & 7.99 & 10.3 & 7.00 & 6.33 & 6.67 & 9.6 \\
\hline GE - 1034 & 39.5 & 35.8 & 37.7 & 9.4 & 5.74 & 6.27 & 6.01 & -9.2 & 37.3 & 34.3 & 35.8 & 8.0 & 8.51 & 8.49 & 8.50 & 0.2 & 8.17 & 7.40 & 7.79 & 9.4 \\
\hline \multirow[t]{2}{*}{ Mean } & 34.6 & 31.3 & 33.0 & 9.5 & 5.59 & 5.57 & 5.58 & 0.4 & 34.4 & 32.2 & 33.3 & 6.4 & 7.13 & 6.79 & 6.96 & 4.8 & 7.54 & 7.08 & 7.31 & 6.1 \\
\hline & SEm & $\mathrm{CD}$ & & & SEm & $\mathrm{CD}$ & & & SEm & $\mathrm{CD}$ & & & SEm & $\mathrm{CD}$ & & & SEm & $\mathrm{CD}$ & & \\
\hline Treatment & 0.50 & 1.30 & & & NS & NS & & & 0.53 & 1.53 & & & 0.022 & 0.06 & & & 0.03 & 0.09 & & \\
\hline Variety & 1.00 & 2.60 & & & 0.14 & 0.40 & & & 1.05 & 3.03 & & & 0.046 & 0.13 & & & 0.06 & 0.17 & & \\
\hline $\mathrm{V} \times \mathrm{T}$ & NS & NS & & & 0.19 & 0.55 & & & NS & NS & & & 0.065 & 0.19 & & & 0.08 & 0.23 & & \\
\hline CV (\%) & \multicolumn{4}{|c|}{6.7} & \multicolumn{4}{|c|}{8.9} & \multicolumn{4}{|c|}{11.6} & \multicolumn{4}{|c|}{3.6} & \multicolumn{4}{|c|}{2.9} \\
\hline
\end{tabular}

C: Control, DS: Moderate drought stress, \% Red.: Per cent reduction under stress, mrl: meter row length of 10 plants, NS: Non-significant, SEm \pm and CD @ 5\%. 
Table.4 Pearson correlation between yield and yield attributes in finger millet genotypes under control and moderate drought stress conditions

\begin{tabular}{|c|c|c|c|c|c|c|c|c|c|c|}
\hline \multirow[t]{2}{*}{ Character } & \multicolumn{5}{|c|}{ Control } & \multicolumn{5}{|c|}{ Drought Stress } \\
\hline & $\begin{array}{l}\text { Grain } \\
\text { yield }\end{array}$ & $\begin{array}{l}\text { Mean } \\
\text { ear wt. }\end{array}$ & $\begin{array}{l}\text { Prod. } \\
\text { tillers/ mrl }\end{array}$ & $\begin{array}{l}\text { Finger } \\
\text { length }\end{array}$ & $\begin{array}{l}\text { Finger } \\
\text { No./ ear }\end{array}$ & $\begin{array}{l}\text { Grain } \\
\text { yield }\end{array}$ & $\begin{array}{l}\text { Mean } \\
\text { ear wt. }\end{array}$ & $\begin{array}{l}\text { Prod. } \\
\text { tillers/ mrl }\end{array}$ & $\begin{array}{l}\text { Finger } \\
\text { length }\end{array}$ & $\begin{array}{l}\text { Finger } \\
\text { No./ ear }\end{array}$ \\
\hline Grain yield & 1.000 & & & & & 1.000 & & & & \\
\hline $\begin{array}{l}\text { Mean ear } \\
\text { weight }\end{array}$ & 0.249 & 1.000 & & & & 0.539 & 1.000 & & & \\
\hline $\begin{array}{l}\text { Prod. tillers/ } \\
\text { mrl }\end{array}$ & -0.088 & -0.664 & 1.000 & & & 0.480 & -0.281 & 1.000 & & \\
\hline Finger length & 0.164 & 0.495 & -0.230 & 1.000 & & 0.301 & 0.734 & -0.229 & 1.000 & \\
\hline Finger No./ ear & -0.222 & 0.745 & -0.536 & 0.439 & 1.000 & 0.512 & 0.651 & -0.051 & 0.150 & 1.000 \\
\hline
\end{tabular}

Table.5 Path coefficient analysis of yield attributes towards grain yield in finger millet genotypes under control and moderate drought stress conditions

\begin{tabular}{|c|c|c|c|c|c|c|c|c|c|c|}
\hline \multirow[t]{2}{*}{ Character } & \multicolumn{5}{|c|}{ Control } & \multicolumn{5}{|c|}{ Stress } \\
\hline & $\begin{array}{l}\text { Mean } \\
\text { ear wt. }\end{array}$ & $\begin{array}{l}\text { Prod. } \\
\text { tillers/ mrl }\end{array}$ & $\begin{array}{l}\text { Finger } \\
\text { length }\end{array}$ & $\begin{array}{c}\text { Finger } \\
\text { No./ ear }\end{array}$ & $\mathrm{R}$ & $\begin{array}{l}\text { Mean } \\
\text { ear wt. }\end{array}$ & $\begin{array}{l}\text { Prod. } \\
\text { tillers/ mrl }\end{array}$ & $\begin{array}{l}\text { Finger } \\
\text { length }\end{array}$ & $\begin{array}{l}\text { Finger } \\
\text { No./ ear }\end{array}$ & $\mathrm{r}$ \\
\hline Mean ear weight & 0.908 & -0.030 & 0.066 & -0.695 & 0.249 & 0.802 & -0.190 & -0.103 & 0.030 & 0.539 \\
\hline Prod. tillers/ mrl & -0.602 & 0.045 & -0.031 & 0.500 & -0.088 & -0.226 & 0.676 & 0.032 & -0.002 & 0.480 \\
\hline Finger length & 0.450 & -0.010 & 0.133 & -0.409 & 0.164 & 0.589 & -0.155 & -0.141 & 0.007 & 0.301 \\
\hline Finger No./ ear & 0.677 & -0.024 & 0.059 & -0.933 & -0.222 & 0.522 & -0.034 & -0.021 & 0.046 & 0.512 \\
\hline
\end{tabular}

mrl: meter row length of 10 plants, r: correlation coefficient 
In the present study, the mean productive tillers per hill were reduced by $6.4 \%$ due to moderate DS (Table 3; Ludlow and Muchow, 1990) probably stress during panicle formation could decrease the conversion of vegetative tiller to productive tiller. Mean ear weight influences the grain yield to a greater extent under a given condition (Nanja Reddy et al., 2019a). In fact the early selection in finger millet was in the direction of ear size, and the ear size will be affected by severe stress (Suma, 2014). In the present study no reduction was observed as the exposure to stress was completed by the time of flowering and subsequent ear development and; mainly it was a mild stress. However, it has been suggested that large ear size with thicker leaves could be more appropriate for rainfed conditions (Sastry et al., 1982). The moderate moisture stress did not affect much the finger length $(4.8 \%)$ and finger number/ ear $(6.1 \%)$ because the stress was relieved by the time of flowering and; the early effect was mild.

Several reports show that, the grain yield was positively related to ear size and productive tillers per unit area (Prakasha et al., 2018; Nanja Reddy et al., 2019a). In addition, the finger number and length are also important for higher grain yield (Rani et al., 20015; Negi et al., 2017; Mahanthesha et al., 2018; Sneha et al., 2019). In the present study, the relationship between grain yield with mean ear weight, productive tillers, finger length and finger number was strong under DS condition as compared to control condition (Table 4). Such contribution under stress condition was confirmed by path analysis. Results of path analysis show that only mean ear weight is important and productive tillers is not a constraint for productivity under control condition; while under DS condition, both mean ear weight and productive tillers are important in determining the grain yield (Table 5).
These results suggests that, moderate drought stress during grand growth stage to flower primordial initiation, affect the gas exchange parameters to a higher extent as compared to the yield and yield attributing traits.

The released varieties are not affected by a moderate DS for 18-20 days with pan evaporation of $4.2 \mathrm{~mm} /$ day in red sandy loam soils. Furthermore, finger millet being a $\mathrm{C}_{4}$ species moderate stress could lead to only a marginal decrease in grain yield. Under DS condition both productive tiller number and ear size are important in grain yield formation, but in control productive tillers was not a constraint for productivity. The better performance of PR-202 in trait per sein the present study and in earlier studies, suggests that it can be termed as relatively drought resistant and can be used as check in genotypic screening for drought resistance.

\section{Acknowledgements}

Authors thank the ICAR- Project Coordinating Unit (Small Millets) for facilitating the conduct of experiment. Authors also thank, Dr. P.S. Jagadish, Dr. A. Nagaraja, Dr. M. Krishnappa, PC Unit (Small Millets) for their support and suggestions in conducting the experiment.

\section{References}

Anitha, K., Sritharan, N., Ravikesavan, R., Djanaguiraman, M. and Senthil, A., 2019. Melatonin alters photosynthesis related traits in finger millet (Eleusine coracana L.) under drought condition. International Journal of Chemical Studies, 7(3): 27502754.

Anonymous, Annual report, 2008. All India Coordinated Small Millets Improvement Project, ICAR, GKVK, Bangalore-65, 16.

Anonymous, 2019. uasbanagalore.edu.in/index.php/researchen/agromateorology-en.

Chethan, S. and Malleshi, N.G., 2007. Finger 
millet poly phenols: Characterization and their nutraceutical potential. American Journal of Food Technology, 2: 618-629.

Daryanto, S., Wang, L. and Jacinthe, P.A., 2014. Global synthesis of drought effects on maize and wheat production. PLOSONE 11:e0156362.

doi: 10.1371/journal.pone.0156362.

Dash, S.K., Kulkarni, M.A., Mohanty, U.C. and Prasad, K., 2009. Changes in the characteristics of rain events in India. Journal of Geophysics Research, 114:D10.

Davis, K.F., Chhtre, A., Rao, N.D., Singh, D. and DeFries, R., 2019. Sensitivity of grain yields to historical climate variability in India. Environmental Research Letters, 14: 064013, http://doi.org/10.1088/17489326/ab22db.

Dida, M. M., Srinivasachary, Ramakrishnan, S., Bennetzen, J.L., Gale, M.D. and Devos, K.M., 2007. The genetic map of finger millet (Eleusine coracana L.). Theoretical and Applied Genetics, 114: 321-332.

Devi, P.B., Vijayabharathi, R., Sathyabama, S., Malleshi, N.G. and Priyadarisini, V.B., 2014. Health benefits of finger millet (Eleusine coracana L.) polyphenols and dietary fiber: A review. Journal of Food Science and Technology, 51: 1021-1040.

Jalihal, C., Srinivasan, J. and Chakraborty, A., 2019. Modulation of Indian monsoon by water vapor and cloud feedback over the past 22,000 years, https://doi.org/10.1038/s41467-019-137546 www.nature.com/naturecommunications.

Gupta, R., Pandey, S.K., Singh, A.K. and Singh, M., 2011. Response of photosynthesis, chlorophyll fluorescence and yield of finger millet (Eleusine coracana) influenced by biochemical fertilizers. Indian Journal of Agricultural Sciences, 81(5): 445-449.

Gupta, S.M., Arora, S., Mirza, N., Pande, A., Lata, C. and Puranik, S., 2017. Finger Millet: a "certain" crop for an "uncertain" future and a solution to food insecurity and hidden hunger under stressful environments. Frontiers in Plant Science, 8: 643 .

Ludlow, M.M. and Muchow, R.C., 1990. A critical evaluation of traits for improving crop yields in water limited environments. Advances in Agronomy, 43:107-153.

Maai, E., Nishimura, K., Takisawa, R. and Nakazaki, T., 2020. Diurnal changes in chloroplast positioning and photosynthetic traits of $\mathrm{C}_{4}$ grass finger millet. Plant Production

Science, DOI: 10.1080/1343943X.2020.175 8171

Mahanthesha, M., Sujatha, M., Meena, A.K. and Pandravada, S.R., 2018. Correlation and path coefficient analysis in finger millet (Eleusine coracana (L.) Geartn.). Journal of Pharmacognosy and Phytochemistry, 7(4): 3193-3196.

Malhotra, S.K., 2018. National conference on agriculture: Kharif campaign, 2018. www.agricoop.gov.in/sites/default/file s/agriculture_commissioner_ppt_1.ppt x

Maqsood, M. and Azam Ali, A.N., 2007. Effects of drought on growth, development, radiation use efficiency and yield of finger millet (Eleusine coracana). Pakistan Journal of Botany, 39(1):123-134.

Mohanabharathi, M., Sritharan, N., Senthil, A. and Ravikesavan, R., 2019. Physiological studies for yield enhancement in finger millet under drought condition. Journal of Pharmacognosy and Phytochemistry, 8(3): 3308-3312.

Nanja Reddy, Y.A., Jayarame Gowda, Ashok, E.G., Krishne Gowda, K.T.and Gowda, M.V.C., 2019a. Higher leaf area improves the productivity of finger millet (Eleusine coracana (L.) Gaertn.) under rainfed conditions. International Journal of Current Microbiology and Applied Sciences, 8(5): 1369-1377.

Nanja Reddy, Y.A., Lavanyabai, T., Prabhakar, Ramamurthy, V., Chame Gowda, T.C., Shankar, A.G. and Gowda, M.V.C., 2019b. Bench mark values for grain iron content in finger millet (Eleusine coracana (L.) Gaertn.). International Journal of Current Microbiology and Applied Sciences, 8(6): 502-506.

Negi, S., Bhatt, A. and Kumar, V., 2017. Character association and path analysis for yield and its related traits in finger millet (Eleusine coracana (L.) Gaertn.) genotypes. Journal of Applied and Natural Science, 
9(3): 1624-1629.

Netravati, H., Geetha, K., Vikram, S.R., Nanja, Y.A., Joshi, N. and Shivaleela, H.B., 2018. Minerals content in finger millet [Eleusine coracana (L.) Gaertn.]: A future grain for nutritional security. International Journal of Current Microbiology and Applied Sciences, Special Issue 7: 3448-3455.

Rani, J., Ratna, B.D., Ahamed, M.L. and Srinivasa, V., 2015. Character association and path coefficient analysis for grain yield and yield components in finger millet (Eleusine coracana (L.) Gaertn.). Electronic Journal of Plant Breeding, 6(2): 535-539.

Sastry, K.S.K., Udayakumar, M. and Vishwanath, H.R., 1982. Desirable plant characteristics in genotypes of finger millet (Eleucine coracana (L.) Gaertn.) for rainfed conditions. Indian National Science Academy, 48:264-270.

Sakamma, S., Umesh, K.B., Girish, M.R., Ravi, S.C., Satishkumar, M. and Bellundagi, V., 2018. Finger millet (Eleusine coracana L. Gaertn.) production system: status, potential, constraints and implications for improving small farmer's welfare. Journal of Agricultural Sciences, 10: 162-179.

Sharma, D., Jamra, G., Singh, U.M., Sood, S. and Kumar, A., 2017. Calcium bio-fortification: three pronged molecular approaches for dissecting complex trait of calcium nutrition in finger millet (Eleusine coracana) for devising strategies of enrichment of food crops. Frontiers in Plant Science.7: 2028.doi: 10.3389/fpls.2016.02028

Sheoran, O. P., Tonk, D. S., Kaushik, L. S., Hasija, R. C. and Pannu, R. S., 1998. Statistical software package for agricultural research workers. Recent advances in information theory, statistics\& computer applications, Department of Mathematics Statistics, CCS HAU, Hisar, 139-143

Sneha, R.S., Bhavsar, V.V., Barhate, K.K. and Sarika, N.K., 2019. Correlation and path analysis for different characteristics in germplasm of finger millet (Eleusine coracana (L.) Gaertn.). International Journal of Current Microbiology and Applied Sciences, 8(1): 1020-1027.

Sage, R.F. and Zhu, X.G., 2011. Exploiting the engine of $\mathrm{C}_{4}$ photosynthesis. Journal of Experimental Botany, 62(9): 2989-3000.

Subramanyam, D. 2000. Genotypic variability in photosynthetic characters in finger millet. Photosynthetica, 38(1): 105-109.

Suma, L.S., 2014. Characterization of selected germplasm accessions for drought tolerance in finger millet (Eleusine coracana). M.Sc. (Agri.) thesis, Department of Crop Physiology, University of Agricultural Sciences, Bangalore, India.

Ueno, O., Kawano, Y., Wakayama, M. and Takeda, T., 2006. Leaf vascular systems in $\mathrm{C}_{3}$ and $\mathrm{C}_{4}$ Grasses: A two-dimensional analysis. Annals of Botany, 97(4): 611 621.

Webb, P. and Braun, V.J., 1994. Famine and food security in Ethiopia. Wiley, New York.

\section{How to cite this article:}

Nanja Reddy, Y.A., Jayarame Gowda, E.G. Ashok and Krishne Gowda, K.T. 2020. Effect of Moderate Drought Stress on Photosynthetic Rate and Grain Yield in Finger Millet Genotypes. Int.J.Curr.Microbiol.App.Sci. 9(05): 2951-2959. doi: https://doi.org/10.20546/ijcmas.2020.905.350 